\title{
Emerging Issues Concerning the Education of Speech and Language Pathologists and Audiologists in Brazil and South America
}

\author{
Fernanda Dreux M. Fernandes Claudia R.F. de Andrade Debora M. Befi-Lopes \\ Haydée F. Wertzner Suelly C.O. Limongi \\ School of Medicine, University of São Paulo, São Paulo, Brazil
}

\section{Key Words}

Speech-language pathology $\cdot$ Audiology $\cdot$ Brazil $•$

South America

\begin{abstract}
Diversity is one of the major characteristics of Brazil and all South America. This paper presents an overview of the current situation of the education of speech and language pathologists (SLP) and audiologists in Brazil and in several other countries of South America. This paper also discusses the main challenges shared by these countries. The discussion is focused on the mutual interferences between education and the areas of professional practice, cultural diversity and continued education. There are many emerging issues about the education of SLP and audiologists in South America. The suggested conclusion is that, despite the many differences, the South American SLP and audiologists' education would benefit from joint efforts and collaborative experiences.
\end{abstract}

Copyright $\odot 2010$ S. Karger AG, Basel

\section{Introduction}

South America is a continent with great variety and many contrasts. Geographically, it spreads from the Caribbean Sea, above the equator, to the Drake Strait in
Patagonia. The world's largest rainforest and its driest desert are located in South America. The continent has a total area of 17.7 million $\mathrm{km}^{2}$ and the latest measurement, in 2002, reported a population of 385 million people [1].

Politically, it comprises 12 countries and 2 colonies (French Guiana and the Falkland Islands). All of these countries have less than 200 years of independent history and most of them had been Spanish or Portuguese colonies until the middle of the 19th century [2]. Therefore, Spanish is the language spoken in most of the countries. Although Portuguese is spoken only in Brazil, this country has a population of over 194 million people, which means that more than half the population of South America speaks Portuguese.

The demographic distribution on this continent is also very irregular. The average density is less than 20 inhabitants per square kilometer, but there are several areas with a high population density. There are 17 cities with more than 2 million inhabitants, 5 with more than 5 million and São Paulo, which has the world's fourth largest metropolitan population, i.e. 11 million in the city and over 19 million in the metropolitan area [3].

There is also a great ethnic variety among the countries. In Uruguay and Argentina, the populations are mostly white (88 and $97 \%$, respectively), while in other countries, the Amerindian influence is most evident, as is the case with Paraguay (95\%), Bolivia (85\%) and Peru

\section{KARGER}

Fax +4161306 1234

E-Mail karger@karger.ch

www.karger.com
(C) 2010 S. Karger AG, Basel

$1021-7762 / 10 / 0625-0223 \$ 26.00 / 0$

Accessible online at: www.karger.com/fpl
Fernanda Dreux M. Fernandes

Rua do Mangericão 301, Granja Viana 2 Cotia, SP 06706-240 (Brazil)

Tel. +55 114702 6028, Fax +55 1130917714

E-Mail fernandadreux@usp.br 
(82\%). In Brazil, the population is described as $53 \%$ white and 39\% 'mulato' (mixed black and white) [4]. This same type of difference can be observed in different regions of some countries.

The literacy rates are fairly homogeneous, with averages around $92 \%$, the highest rate of $98 \%$ in Uruguay and the lowest rate of $86.7 \%$ in Bolivia. The data about university education, however, present an enormous diversity, even when considering differences in educational policy and population size. While in Brazil there are over 900 universities, in Bolivia there are 35 universities, in Argentina 33, in Chile 22 and in Colombia 16. In Uruguay and Paraguay there are only 6 universities in each country, and only 4 in Venezuela.

\section{Speech and Language Pathology and Audiology in South America}

The audiology practices as well as the speech and language clinical and therapeutic approaches constitute the educational curriculum of 'fonoaudiologia' in all of the South American countries where there are educational programs in the field (i.e. in South America, speech and language pathology and audiology are considered one single profession with several areas of knowledge).

Argentina has played a key role in the history of 'fonoaudiologia' in South America. There are 3 undergraduate programs, 12 graduation courses and 3 doctorate programs in this country.

On the other hand, the first undergraduate programs in Paraguay started just in 2007 and 2008, and there are still no graduated professionals there. The first 'fonoaudiólogos' were registered in 1991 and the majority of them had graduated in Brazil. One significant issue is that the professors of the programs that have recently started do not have master's or doctoral degrees.

Venezuela presents a reality still different: for more than 50 years, a technical specialty has existed in language therapy, involving a 3-year training program. Recently, the career of 'fonoaudiólogo' at university level has been approved and 2 undergraduate programs should begin in the near future. There are only 2 professionals who have obtained their doctoral degrees, one in audiology and the other in language, in the USA.

There are approximately 30 speech and language pathologists (SLP) and audiologists in Bolivia and no educational program in the area exists in this country. Two of the professionals have obtained their doctoral degrees in the USA and only 6 of them work in the field of audiol- ogy. Individuals who need speech, language or audiology services are usually attended by special teachers, nurses, psychologists or physiotherapists.

In Peru, the career of 'fonoaudiólogo' does not exist. The work in this field is usually performed by health technicians who are specialists in language and communication disorders or in hearing and language. Some of them have master's degrees in education.

Colombia has 11 undergraduate courses in 'fonoaudiologia' and the career has officially been regulated since 1997. The description of the professional abilities required includes research, teaching, management, assistance and orientation in the areas of speech, language and hearing.

There is an important movement towards the development of speech and language pathology and audiology in Chile. Although there are still no professionals with doctoral degrees in this country, 2 master's programs are conducted, mostly with the contribution of experienced foreign professors invited to present courses and seminars. The Revista chilena de fonoaudiologia (Chilean Speech-Language Pathology and Audiology Journal) is indexed in the database LILACS (Literatura LatinoAmericana e do Caribe em Ciências da Saúde), indicating the journal's quality and allowing the dissemination of knowledge. Recently, public educational programs for children have created a great demand for SLP, which in turn has resulted in an increase in the number of undergraduates in the area.

The comparison of different realities shows, for example, that there is 1 'fonoaudiólogo' to every 10,400 inhabitants in Chile and 1 for every 6,400 inhabitants in Brazil. These data are illustrated in table 1.

\section{Speech and Language Pathology and Audiology in Brazil}

In Brazil, the first official undergraduate programs began around 1958 with services for deaf children in major hospitals although there have been reports of rehabilitation programs for deaf children since the 19th century. Until the end of the 1970s, there were only 3 undergraduate programs, all of them in the city of São Paulo. During the 1980s, there was a large increase in the number of programs that eventually reached other regions of the country [5]. Still, even nowadays, most of the undergraduate and graduate courses are located in the south and southeast regions of Brazil. Today, there are over 30,000 SLP/audiologists in Brazil. 
Table 1. Overview of speech and language pathology and audiology in South America

\begin{tabular}{|c|c|c|c|c|}
\hline & \multicolumn{2}{|l|}{ Programs } & \multirow[t]{2}{*}{ Doctorate } & \multirow[t]{2}{*}{ Career } \\
\hline & undergraduate & graduate & & \\
\hline Argentina & 3 & 12 & 3 programs & 40 years \\
\hline Paraguay & 2 & none & none & Brazilian SLP since 1991 \\
\hline Venezuela & 2 still starting & none & $\begin{array}{l}2 \text { doctors in the whole country; } \\
\text { no program }\end{array}$ & 50 years; technical level \\
\hline Bolivia & none & none & 2 doctors in the whole country & $\begin{array}{l}30 \text { SLP and audiologists in } \\
\text { the whole country }\end{array}$ \\
\hline Peru & \multicolumn{4}{|c|}{ no SLP or audiologists in the country; similar work carried out by special educators } \\
\hline Colombia & 11 & not informed & not informed & exists in the country since 1997 \\
\hline Chile & 16 & 3 & none & $\begin{array}{l}1,320 \text { SLP and audiologists } \\
\text { in the country }\end{array}$ \\
\hline Brazil & $>80$ & $\begin{array}{l}8 \text { master's programs; } \\
\text { several specialization courses }\end{array}$ & $\begin{array}{l}3 \text { programs; }>300 \text { doctors in } \\
\text { the whole country }\end{array}$ & $\begin{array}{l}>50 \text { years; }>30,000 \text { SLP and au- } \\
\text { diologists in the country }\end{array}$ \\
\hline
\end{tabular}

However, these demographic differences related to the distribution of SLP and audiologists are not very different from those observed for the general population. As mentioned earlier, there is a very uneven population distribution in Brazil as well as in all South America.

During the last 2 decades, the number of professionals with master's and doctoral degrees has also increased significantly. Nowadays, there are more than 300 SLP/audiologists with doctoral degrees in Brazil. Some of these professionals obtained their master's and doctoral degrees in different areas, such as in psychology, linguistics and education, or abroad.

Only in the last decade has the number of field-specific master's and doctorate programs increased, but they are still concentrated in the south and southeast regions of Brazil. There are 6 master's programs and 2 programs with master's and doctoral degrees. The research produced in these programs allowed the consolidation of 4 scientific journals that are now indexed in international databases: the Revista pro-fono de atualização científica is included in MEDLINE; the Revista CEFAC and the Revista da Sociedade Brasileira de Fonoaudiologia (Journal of the Brazilian Society of Speech-Language Pathology) are indexed in the Scientific Electronic Library Online (SciELO), and the Revista disturbios da comunicação (Journal of Communication Disorders) is indexed in LILACS. The number of papers published in these journals has increased by $27.2 \%$ in the last 3 years; they have discussed themes such as language (45.6\%), audiology

Education of SLP and Audiologists in Brazil and South America
(23.8\%), oral myology and swallowing (20.8\%), and voice $(9.8 \%)$.

There are many emerging issues about the education of SLP and audiologists in a developing country such as Brazil. Many of the issues that interfere with professional practice and education are the problems the country faces as a whole.

\section{Issue 1: Education, Professional Practice and Health Policies}

The increase in the number of 'fonoaudiólogos' has not been accompanied by advances in public health policies or health insurance coverage; thus, most of the population does not have access to speech, language and hearing services. Therefore, the lack of job positions for recently graduated professionals has resulted in a decrease in the number of pupils interested in the area.

This poses one of the major challenges to the education of SLP and audiologists in Brazil in the third millennium.

While keeping up and maintaining a quality-based teaching approach, it is imperative to give the general population access to speech, language and audiology services. In some regions of the country, this is also one of the roles played by the universities.

In Brazil, the basic needs of a large portion of the population, such as housing and feeding, are just now being 
attended. Speech, language and hearing services are part of the health system. However, public health policies have still not given these services the required priority. Very few public health units include a 'fonoaudiólogo' in their multiprofessional teams (i.e. most 'fonoaudiólogos' work in private practices).

Education has a commitment to evidence-based practice, providing scientific support to speech, language and hearing services, and reinforcing the importance of human communication to quality of life.

\section{Issue 2: Education and Cultural Diversity}

Access to information and education in some regions of Brazil is so precarious that many universities have outof-campus programs designed to meet these issues. Unfortunately, just a few of these programs include SLP or audiologists. For those that do include these professionals, the biggest challenge is to deal with groups with very different characteristics and cultures, not forgetting to protect and respect these differences while providing every individual with opportunities for inclusion into the largest mainstream part of society.

It is undoubtedly a challenge to provide students, e.g. from São Paulo, one of the major cities of the world, with instruments, parameters and criteria by which they can evaluate a child who lives healthily and happily, for example, on the margins of the Amazon river. The question prompted is: should this child be expected to meet criteria developed to evaluate children who have access to TVs, computers and mobile phones, or does the choice of applying any criteria more loosely jeopardize the capability of this child to compete with others in a highly competitive society?

Obviously one cannot (or should not) expect this type of question to be answered by an undergraduate student. However, this issue should be part of health and education policies discussed and enforced by universities, based on the development of knowledge which is applicable to specific situations such as the example mentioned above.

The same would be true for several other situations in all of South America, such as regarding specific cultural groups and different needs determined by different access to cultural, communication and production means. If the issue of social equality is to be seriously considered, the importance of communicative effectiveness to social mobility must be carefully and cautiously addressed.
The general 'fonoaudiólogo', e.g. working in a small town on either side of the Brazilian south-southeast axis, may be the professional that, 15 years ago, went through an undergraduate program with almost $5,000 \mathrm{~h}$ of theoretical and practical teaching, eventually enrolled in a specialization course and, from then on, has read just a few books or attended some conferences or short courses. Normally, this professional receives patients with all types of disorders and, eventually, will have a different part-time job conducting audiometric evaluations.

Or the general 'fonoaudiólogo' may be the professional working in a small town near São Paulo or Curitiba after graduation, for example. He/she may have competed successfully with other health professionals for a scholarship in a graduate and/or doctorate program, have a research activity and publish his/her work in indexed journals. Normally, this professional receives patients within his/her specific field and keeps him- or herself updated by reading international papers accessing international databases.

Both professionals do the best work they can. But they face completely different needs and challenges. The sole 'fonoaudiólogo' in a relatively isolated city or town does not need to and should not be a specialist because he/she must be able to provide different types of services to different needs. However, he/she must have access to information and knowledge in order to guarantee the quality and recycling of his/her practice.

On the other hand, the SLP or audiologist working in a competitive environment should be a specialist in order to improve his/her knowledge in a specific area. The recycling and research production are essential to enable the SLP or audiologist to compete with other areas of the health sciences for sponsorships and research funding on an equal basis.

\section{Issue 3: Continued Education and Future Perspectives}

Another important challenge to the education of SLP and audiologists in Brazil, and probably in all of South America, involves the ongoing education policies.

In Brazil, the current criteria for accreditation as a specialist include an analysis of the participation in formal courses, scientific activities and a written test. The greatest change, however, is the fact that since 2007, this accreditation as a specialist has to be renewed every 3 years via a predetermined amount of points obtained by scientific and recycling activities and courses, like in the USA. 
This implies a change of habit, demanding the professional to effectively keep him- or herself updated and, therefore, constantly improve his/her professional practice. Stimulating SLP and audiologists to join scientific societies, to renew their specialized accreditation and to subscribe scientific journals will probably contribute to the improvement in the quality of general practice.

In the near future, technological development will probably facilitate the recycling of professionals who choose to live and work in developing areas and are therefore geographically far from important knowledge production centers. Many universities, scientific societies and educational institutions are developing distance education programs and specific software for professional training [6].

The current criteria for the evaluation of master's and doctoral programs implemented by the Brazilian federal regulatory agency become increasingly more demanding. One of the major issues involved in this evaluation is the fact that the federal agency demands international publications. These publications should be presented as by-products of developed studies. On the other hand, there is a growing need for language-specific studies that provide parameters and guidelines specific to the Brazilian Portuguese language. However, specific language-related issues do not seem to be of interest to most of the international journals in this field of knowledge. This way, international publication is a challenge to be faced by all: scientific associations, publication organizations, editors as well as educational institutions of the whole world.

Recently, the issues related to language diversity have been addressed in several ways. Student mobility programs are just now being implemented (specifically be- tween Brazil and Chile) and their results should be published soon.

The Sociedade Brasileira de Fonoaudiologia is responsible for organizing the annual Brazilian Speech-Language Pathology and Audiology Conference. In 2009, this conference will also be the first Ibero-American Speech-Language Pathology and Audiology Conference, having as a theme: Fonoaudiologia - Knowledge and Integration. The aim of the conference is to improve the integration of educational programs and research projects produced in South America, Portugal and Spain.

\section{Conclusion}

This paper addresses important issues involved in the education of SLP and audiologists in Brazil and South America. The topics discussed involved education, professional practice and health policies; education and cultural diversity, and continued education and future perspectives.

Despite the great differences between the South American countries, there are several common problems, some shared history and still very little experience in cooperation. Improving the information exchange may provide opportunities for the development of solutions that may be applicable to similar situations in different regions of the continent. This is not really a challenge, it is a task that must be undertaken by all the individuals and institutions involved.

The need to bridge the wide gaps between different realities demands specific solutions and yields to different perspectives. This is our challenge.

\section{References}

1 United Nations Statistics Division: Demographic and social statistics, 2008. http://unstats.un.org/unsd/demographic/products/ socind/population.htm (accessed January 21, 2009).

2 Giddens A: Cambio social en el mundo moderno. Madrid, Alianza Universidad Textos, 1996.
3 International Center for Tropical Agriculture: Animations of population change in Central America, the Amazon Basin and the Southeast coast of South America: Cali, Colombia. http://gisweb.ciat.cgiar.org/population/map.htm (accessed January 21, 2009).

4 Central Intelligence Agency USA: The 2008 world factbook. https://www.cia.gov/library/publications/the-world-factbook/ geos/pa.html (accessed January 21, 2009).
5 Behlau M, Gasparini G: Education of speechlanguage pathologists and audiologists in Brazil. Folia Phoniatr Logop 2006;58:14-22.

-6 Chen Li-Rong L: Global perspective of speech pathology education. Folia Phoniatr Logop 2006;58:5-6. 